\title{
Decreased Attention
}

National Cancer Institute

\section{Source}

National Cancer Institute. Decreased Attention. NCI Thesaurus. Code C117245.

Impaired ability to focus on a subject or idea. 